\title{
Czy należy stosować radioterapię w chłoniaku rozlanym z dużych komórek B? Głos na nie
}

\author{
Jan Walewski
}

Should radiotherapy be used in diffuse large B-cell lymphoma? Vote for NO

Pytanie tytułowe odnosi się do istnienia imperatywu stosowania radioterapii w leczeniu chorych na DLBCL, który musiałby wynikać ze znanych i uznanych dowodów większej skuteczności i/lub mniejszej toksyczności metod leczenia zawierających radioterapię w porównaniu z metodami leczenia systemowego bez radioterapii.

Według mojej oceny takich wiarygodnych dowodów nie ma i radioterapia może być stosowana jako postępowanie uzupełniające lub alternatywne w celu opanowania problemu miejscowego wówczas, kiedy optymalne leczenia systemowe nie może być zastosowane lub w razie niepowodzenia leczenia standardowego.

Argumenty za stosowaniem radioterapii w leczeniu pierwotnym DLBCL mają generalnie niski poziom dowodowy i niski stopień rekomendacji, opierają się na nielicznych badaniach porównawczych, często obarczonych istotnymi wadami, a rekomendacje międzynarodowe są niejednoznaczne. Zalecenia ESMO z 2012 r. [1] przewidują radioterapię (RT) po immunochemioterapii R-CHOP21 jedynie jako możliwość alternatywną dla chorych w wieku 60 I. lub młodszych ze zmianą masywną czy z jednym niepomyślnym czynnikiem rokowniczym IPI.Takiego zalecenia nie ma natomiast dla chorych starszych ani dla młodszych z liczbą czynników niepomyślnych większą niż jeden.

Zalecenia NCCN z 2013 r. [2] przewidują RT jako postępowanie alternatywne („£ RT") dla przypadków w stadium ograniczonym (CS I, II). Dla przypadków CS I, II bez zmiany masywnej zalecenie dotyczące leczenia indukcyjnego brzmi: $\mathrm{RCHOP} \times 3 \pm \mathrm{RT}$ lub RCHOP $\times 6 \pm \mathrm{RT}$, z tym że w przypadku nieobecności czynników ryzyka zalecenie to jest skate- goryzowane pod względem mocy dowodowej i stopnia jednomyślności jako 2B. Dla przypadków CS I, II ze zmiana masywną ( $\geq 10 \mathrm{~cm}$ ), zalecenie brzmi: RCHOP $\times 6 \pm$ RT (kategoria 1). Dla przypadków choroby zaawansowanej (CS III, IV) RT nie jest przewidziana (kategoria 1).

Zatem zalecenia europejskie i amerykańskie nie zawierają jednoznacznego wymogu włączenia RT do leczenia indukcyjnego DLBCL, lecz — w zdefiniowanych kategoriach rokowniczych — pozostawiają decyzję do uznania lekarza.

Ta niejednoznaczność wynika, jak już wspomniano, z niedostatków publikowanych badań. Rola RT w leczeniu indukcyjnym DLBCL w stadium ograniczonym była przedmiotem 4 randomizowanych badań prospektywnych (tab. I).

Badanie SWOG 8736 [3], które na początku ubiegłej dekady było uważane za ustanawiające krótką chemioterapię i napromienianie uzupełniające jako standard postępowania w przypadkach choroby ograniczonej bez zmiany masywnej ze względu na znamienne wydłużenie 5-letniego czasu wolnego od progresji ( $77 \%$ vs $64 \%$ ) i czasu przeżycia ( $82 \%$ vs 72\%), jak również zmniejszenie toksyczności w porównaniu

Tabela I. Badania porównujące chemioterapię i chemioterapię + RT w stadium ograniczonym DLBCL (CS I, II)

\begin{tabular}{lcc}
\hline Akronim & Ramiona badania & Publikacja \\
\hline SWOG 8736 & CHOP $\times 3+$ RT vs CHOP $\times 8$ & $1998[3,4]$ \\
ECOG 1484 & CHOP $\times 8$ vs CHOP $\times 8+$ RT & $2004[5]$ \\
GELA LNH 93-1 & CHOP $\times 3+$ RT vs ACVBP + MIEA & $2005[6]$ \\
GELA LNH 93-4 & CHOP $\times 4$ vs CHOP $\times 4+$ RT & $2007[7]$ \\
\hline
\end{tabular}


z 8 kursami CHOP, po upływie kolejnych 3 lat obserwacji [4] nie wykazało już różnic w PFSi OS w związku z wystąpieniem późnych nawrotów, a ponadto wykazało większą częstość zgonów z powodu chłoniaka u pacjentów, którzy otrzymali 3 kursy CHOP [2]. Skróconą chemioterapię i napromienianie należy zatem uznać za leczenie suboptymalne w DLBCL CS I, II.

Badanie ECOG 1484 [5] dotyczyło chorych na DLBCL w stadium zaawansowania I ze zmianą masywną oraz w stadium II, a jego celem było ustalenie, czy konsolidujące napromienianie (30 Gy) okolicy uprzednio zajętej po uzyskaniu całkowitej remisji (CR) po 8 kursach CHOP może poprawić czas wolny od choroby (DFS). Wszyscy chorzy, którzy uzyskali częściową remisję (PR), byli napromieniani po zakończeniu chemioterapii. Badanie to, opublikowane po 12 latach od jego zakończenia, w którym do ramienia IFRT zrandomizowano tylko 79 chorych, a do obserwacji - 93, wykazało przewagę IFRT w zakresie 6-letniego DFS o granicznej znamienności statystycznej (73\% vs 56\%, p = 0,05). Czas przeżycia całkowitego (OS) nie różnił się znamiennie statystycznie, a główną przyczyną niepowodzeń był nawrót systemowy. Trudno uznać to badanie za przekonujące o wartości napromieniania konsolidującego całkowitą remisję.

Badanie LNH 93-1 [6] dotyczyło chorych na DLBCL w stadium ograniczonym, o niskim ryzyku, których mediana wieku wynosiła 47 I., i polegało na randomizacji między leczeniem uważanym za standardowe $-\mathrm{CHOP} \times 3+\mathrm{RT}$ i intensywną chemioterapią ACVBP (doksorubicyna, cyklofosfamid, windezyna, bleomycyna, prednison), po której następowała sekwencyjna konsolidacja z zastosowaniem metotreksatu, etopozydu, ifosfamidu i cytarabiny. Zarówno 5-letni czas wolny od wydarzeń (EFS), jak i OS były znamiennie statystycznie gorsze w przypadku leczenia skojarzonego w porównaniu z chemioterapią bez RT (odpowiednio, 74\% vs $82 \%$ i $81 \%$ vs $90 \%, \mathrm{p}=0,01$ ).

Kolejne badanie tej samej grupy, LNH 93-4, polegało na porównaniu chemioterapii $\mathrm{CHOP} \times 4$ i leczenia skojarzonego - CHOP $\times 4+$ IFRT u chorych w wieku ponad 60 I. 5-letni EFS i OS w obu ramionach badania wyniósł odpowiednio $61 \%$ vs $64 \%, p=0,56$ i $72 \%$ vs $68 \%, p=0,54$ [7]. Badaniu temu zarzucano wprawdzie wady metodyczne [9], jak późny początek RT (mediana 7 tygodni po chemioterapii), niepełną zgodność leczenia z protokołem (12\% chorych w ramieniu RT nie otrzymało RT) i spory odsetek nawrotów w polu RT (21\%), ale główną przyczyną niepowodzeń był nawrót systemowy, a radioterapia w żaden sposób nie poprawiała EFS ani OS.

Retrospektywna ocena 469 chorych [8] na DLBCL we wszystkich stadiach zaawansowania leczonych z zastosowaniem R-CHOP i - w części przypadków - konsolidującego napromieniania w jednym ośrodku (M.D. Anderson Cancer Center, Texas, USA) jest cytowana [9] jako poważna przesłanka za stosowaniem RT ze względu na wysoce znamienne statystycznie różnice 5-letniego PFS i OS na korzyść chorych napromienianych (82\% vs 59\% i $91 \%$ vs $68 \%)$. Tymczasem praca ta może mieć wyłącznie znaczenie hipotetyczne, a nie dowodowe, nie tylko dlatego, że jest retrospektywna, ale z uwagi na to, że kwalifikacja do napromieniania była wynikiem uznania lekarza i dotyczyła $54 \%$ chorych w stadium I, II oraz 14\% w stadium III, IV. Była zatem w oczywisty sposób wynikiem indywidualnej selekcji chorych. Autorzy podają, że spośród chorych, którzy uzyskali CR (74\%), u 63 pacjentów nastąpił nawrót (18\%), który w przypadku chorych napromienianych miał miejsce poza polem RT, i traktują tę obserwację jako dowód $100 \%$ kontroli miejscowej w polach napromienianych. Jednakże jest to zarazem dowód braku wyleczenia mimo uzupełniającej radioterapii. Czas obserwacji chorych (mediana 36 miesięcy) jest zbyt krótki dla oceny ewentualnych efektów odległych napromieniania.

Inne niedawne retrospektywne badanie z pojedynczego ośrodka (Duke University Medical Center) dotyczyło 79 chorych na DLBCL w stadium III, IV, leczonych w okresie 18 lat. RT okolic zajętych (mediana dawki 25 Gy) otrzymało 48\% chorych wg uznania lekarza po uzyskaniu negatywnych wyników badań obrazowych na zakończenie leczenia systemowego (RCHOP, CHOP lub inne). Konsolidujące napromienianie wiązało się z lepszą miejscową kontrolą choroby (92\% vs 69\%) i lepszym EFS (85\% vs 65\%), ale bez istotnego wpływu na czas przeżycia całkowitego [10].

Interesujące badanie randomizowane fazy III dotyczyło oceny wpływu dawki napromieniania na skuteczność kontroli miejscowej u chorych na różne rodzaje chłoniaków (agresywnych i indolentnych), we wszystkich stadiach zaawansowania i w dowolnej linii leczenia. Wszyscy oni „wymagali napromieniania". U chorych na chłoniaki indolentne (grudkowe i strefy brzeżnej) porównywano dawki 40-45 Gy w 20-23 frakcjach i 24 Gy w 12 frakcjach, a u chorych na chłoniaki agresywne (DLBCL), dawki:40-45 Gy w 20-23 frakcjach i 30 Gy w 15 frakcjach. Badanie nie wykazało istotnego statystycznie wpływu dawki napromieniania na częstość odpowiedzi, częstość nawrotów w polu napromieniania, PFS ani OS. Nie było też istotnych różnic toksyczności napromieniania w zależności od dawki, z wyjątkiem istotnej redukcji częstości rumienia w polu napromienianym w przypadku zastosowania mniejszych dawek [11]. Badanie to oczywiście nie wnosi żadnych danych przydatnych w dyskusji na temat celowości napromieniania chorych na DLBCL, ale budzi nową wątpliwość ze względu na wykazany brak zależności efektu od dawki napromieniania, i to zarówno efektu terapeutycznego, jak i toksycznego.

Biorąc pod uwagę dotychczas przytoczone dane, należy stwierdzić, że nie ma przekonujących dowodów większej skuteczności leczenia skojarzonego z radioterapią niż optymalnej immunochemioterapii chorych na DLBCL, zarówno w kontekście choroby ograniczonej, jak i zaawansowanej. 
W przypadku rzadkich umiejscowień pozawęzłowych dane są jeszcze bardziej rozproszone i rozbieżne.

Na przykład w przypadku pierwotnego chłoniaka śródpiersia z dużych komórek B (PMBL) zwyczajowo jest stosowana radioterapia uzupełniająca po zakończeniu chemioterapii, mimo że nie są dostępne badania porównawcze (w szczególności randomizowane), które uzasadniałyby takie postępowanie. Przeciwnie, ostatnie doniesienia dotyczące infuzyjnej [12] lub zintensyfikowanej [13] immunochemioterapii wskazują na doskonałe wyniki — plateau krzywej przeżycia po roku od zakończenia leczenia na poziomie ponad $90 \%$ bez zastosowania uzupełniającej radioterapii.

Opublikowane ostatnio badanie randomizowane z ośrodka onkologicznego w mieście Meksyk, wskazujące na dramatyczną różnicę PFS i OS na korzyść napromieniania, należy uznać za metodycznie wątpliwe, ponieważ - mimo iż 98\% chorych osiągnęło całkowitą remisję — skądinąd nie podano konkretnych kryteriów oceny odpowiedzi, nawroty choroby następowały nieprzerwanie w obu ramionach badania w okresie 10 lat [14]. Ta obserwacja budzi wątpliwości także co do rozpoznania choroby (nie podano kryteriów rozpoznania PMBL innych niż odczyn CD20), ponieważ w tej jednostce chorobowej nawroty po upływie roku od zakończenia leczenia należą do kazuistycznej rzadkości.

Jednostką chorobową, w której radioterapia jest stosowana zwyczajowo i powszechnie mimo braku dowodów korzyści dla chorych, przy obecności licznych dowodów dewastującej toksyczności, jest pierwotny chłoniak ośrodkowego układu nerwowego (DLBCL CNS). U chorych w wieku ponad 60 I. częstość encefalopatii po uzupełniającej radioterapii OUN wynosi $70 \%$, a u młodszych - 40\%. Natomiast niedawno opublikowane badanie randomizowane fazy III grupy niemieckiej (75 ośrodków), w którym po chemioterapii zawierającej metotreksat w wysokich dawkach $\left(4 \mathrm{~g} / \mathrm{m}^{2}\right)$ chorych kwalifikowano do uzupełniającego napromieniania całego mózgowia (45 Gy w 30 frakcjach), nie wykazało wpływu RT na przeżycie chorych [15].

Analogiczny wniosek dotyczy pierwotnego DLBCL w pierścieniu Waldeyera i wynika z retrospektywnej analizy [16] dużej liczby chorych $(n=184)$ przez IELSG (International Extranodal Lymphoma Study Group).

Dla zachowania całości obrazu należy powiedzieć, że niewątpliwą zaletą radioterapii jest znaczna skuteczność w zakresie miejscowej kontroli choroby. Jednak kontrola miejscowa jest sukcesem wyłącznie miejscowym, a większość niepowodzeń ma charakter systemowy. Ponadto toksyczność radioterapii nie może być niedoceniona. Nie chodzi o toksyczność tylko miejscową — jak w przypadku DLBCL CNS, w którym encefalopatia z narastającą demencją i zależnością chorych od opieki pielęgnacyjnej czyni eliminację chłoniaka zwycięstwem pyrrusowym. Napromienianie śródpiersia, oprócz potencjalnego efektu onkogennego wobec sąsiednich tkanek (np. piersi, płuca), prowadzi do głębokiej depopulacji krążących limfocytów T - w ciągu ok. 60 sekund potrzebnych do podania 1 frakcji, w polu napromieniania pojawia się cała objętość krwi (objętość minutowa serca), stąd trudne do przewidzenia konsekwencje immunosupresji.

Zastosowanie radioterapii w leczeniu chorych na DLBCL wymaga dalszych badań prospektywnych, zarówno klinicznych, jak i radiobiologicznych.

\section{Prof. dr hab. n. med. Jan Walewski}

Klinika Nowotworów Układu Chłonnego

Centrum Onkologii — Instytut im. Marii Skłodowskiej-Curie

ul. W.K. Roentgena 5, 02-781 Warszawa

e-mail:walewski@coi.waw.pl

\section{Piśmiennictwo}

1. Tilly $\mathrm{H}$, Vitolo $\mathrm{U}$, Walewski J i wsp. Diffuse large B-cell lymphoma (DLBCL): ESMO Clinical Practice Guidelines for diagnosis, treatment and follow-up. Ann Oncol 2012; 23 (Supplement 7): vii78-vii82.

2. NCCN Guidelines Version 1.2013 Diffuse Large B-Cell Lymphoma. http://www.nccn.org/professionals/physician_gls/, dostęp 23.03.2013.

3. MillerTP, Dahlberg S, Cassady JR i wsp. Chemotherapy alone compared with chemotherapy plus radiotherapy for localized intermediate- and high-grade non-Hodgkin's lymphoma. N Eng J Med 1998; 339: 21-26.

4. MillerTP, LeBlanc M, Spier CM i wsp. CHOP alone compared to CHOP plus radiotherapy for early aggressive non-Hodgkin's lymphoma: update of the Southwest Oncology Group (SWOG) randomized trial. Blood 2001; 98: 724a.

5. Horning SJ, Weller E, Kim Ki wsp. Chemotherapy with or without radiotherapy in limited-stage diffuse aggressive non-Hodgkin's lymphoma. Eastern Cooperative Oncology Group study 1484. J Clin Oncol 2004; 22: 3032-3038.

6. Reyes F, Lepage E, Ganem Gi wsp. ACVBP versus CHOP plus radiotherapy for localized aggressive lymphoma. NEng J Med 2005; 352: 1197-1205.

7. Bonnet C, Fillet G, Mounier N i wsp. CHOP alone compared with $\mathrm{CHOP}$ plus radiotherapy for localized aggressive lymphoma in elderly patients. A study by the Groupe d'Etude des Lymphomes de l'Adulte. J Clin Oncol 2007; 25: 787-792.

8. Phan J, Mazloom A, Medeiros LJ i wsp. Benefit of consolidative radiation therapy in patients with diffuse large B-cell lymphoma treated with R-CHOP chemotherapy. J Clin Oncol 2010; 28: 4170-4176.

9. Yahalom J. Radiation Therapy after R-CHOP for diffuse large B-cell lymphoma: the gain remains. J Clin Oncol 2010; 28: 4105-4107.

10. Dorth JA, Prosnitz LR, Broadwater G i wsp. Impact of consolidation radiation therapy in stage III-IV diffuse large B-cell lymphoma with negative post-chemotherapy radiologic imaging. Int J Radiation Oncol Biol Phys 2012; 84: 762-767.

11. Lowry L, Smith P, Qian W i wsp. Reduced dose radiotherapy for local control in non-Hodgkin lymphoma: a randomised phase III trial. Radiotherapy Oncol 2011; 100: 86-92.

12. Dunleavy K, Pittaluga S, Maeda LS i wsp. Dose-adjusted EPOCH-Rituximab therapy in Primary Mediastinal B-Cell Lymphoma. N Eng J Med 2013; 368: 1408-1416.

13. Romejko-Jarosińska J, Paszkiewicz-Kozik E, Domańska-Czyż K i wsp. Pierwotny chłoniak śródpiersia — wyniki leczenia 65 chorych z zastosowaniem intensywnej, naprzemiennej immunochemioterapii w Instytucie Onkologii w Warszawie. Nowotwory Journal of Oncology 2012; 62 (S2): 132, Streszczenie O24.

14. Avilés A, Neri N, Fernández R i wsp. Randomized clinical trial to assess the efficacy of radiotherapy in primary mediastinal large B-lymphoma. Int J Radiation Oncol Biol Phys 2012; 83: 1227-1231 (Retrakcja artykułu 15.07.2012 r.).

15. Thiel E, Korfel A, Martus P i wsp. : High-dose methotrexate with or without whole brain radiotherapy for primary CNS lymphoma (G-PCNSL-SG-1): a phase 3, randomised, non-inferiority trial. Lancet Oncology 2010; 11: 1036-1047.

16. Mian M, Ferreri AJM, Rossi A i wsp. Role of radiotherapy in patients with early-stage diffuse large B-cell lymphoma of Waldeyer's ring in remission after anthracycline-containing chemotherapy. Leukemia Lymphoma 2013; 54: 62-68. 